\section{UNIVERSITY \\ of DEBRECEN \\ FACULTY OF \\ HEALTH}

NYÍREGYHÁZA

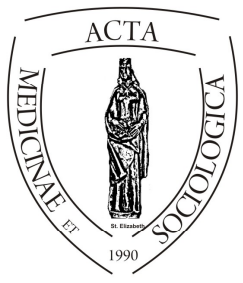

ACTA

MedSoc

VOLUME 5.

2014

\title{
A vállalati elit és a kapcsolati tőke viszonyának elemzése
}

\author{
Makszim Györgyné \\ Nyíregyházi Főiskola, Gazdálkodástudományi Intézet
}

\begin{abstract}
Összefoglalás: A vállalati elit, mint szociológiai fogalom vizsgálata nehezen képzelhetö el a csoportképzésben szerepet játszó befolyásoló tényezők ismerete és vizsgálata nélkül. Jelen tanulmányban a befolyásoló tényezők közül a ma már önálló erőforrást képező kapcsolati tőke szerepét kívánom kiemelni, melynek hatása nem közvetlenül érvényesül, azonban mégis jelentős, éppen ezért tekintem külön vizsgálati terepnek. A kapcsolati tőke hatása már csak azért is közvetett, mert nemcsak egy szociológiai csoport ('́gy a vállalati elit) jellemzésében játszik szerepet, hanem a gazdasági élet „föszereplöin” (a vállalkozókon) keresztül, a vállalkozói szféra által fejti ki hatását a gazdasági, társadalmi folyamatokra.
\end{abstract}

\begin{abstract}
Networking capital - as a resource becoming gradually more and more valuable and becoming a resource on its own - can be linked to the existence, limits and even the internal structure of a company. The essence of a company can be the efficient organisation of networking capital. The concept of networking capital has a rather complex content, thus even today we cannot speak about a single definition. There are several approaches, most of which regard networking capital as a partial alternative of social capital.

My theory gives a more significant role to the entrepreneur in obtaining and coordinating networking capital. These jointly suppose dynamic environment. Basically networking capital may explain efficiency issues and challenges of the economic changes of the environment.

The results of the empirical research show that in most cases there is a significant connection between the structural characteristics of the enterprises and the networking
\end{abstract}


capital; the direction and the magnitude of the impacts can be determined and measured by appropriate statistical tests and analytical methods.

Keywords: networking capital, enterprise elit, company, entrepreneur, structural characteristics of the enterprises, empirical research, probability connection, questionnaire survey, sample

DOI: $10.19055 / \mathrm{ams} .2014 .5 / 14-15 / 7$

\section{A témaválasztás indoklása}

A témaválasztásban egyértelmüen közgazdasági végzettségem, illetve az ezen a területen folytatott tudományos tevékenységem játszott motiváló szerepet. Jelenleg ugyanis a „Vállalatelmélet és Gyakorlat Doktori Iskola” (ME-GTK) PhD hallgatója vagyok, kutatási témám: Szabolcs-Szatmár-Bereg megye vállalkozási szerkezetének statisztikai elemzése, illetve a gazdasági folyamatok és a vállalkozási jellemzők közötti összefüggések vizsgálata. E téma utolsó összetevője (,vállalkozási jellemzők”) adta meg a lehetőségét, hogy a vállalati elitet a kapcsolati tőke összefüggésében vizsgáljam. A vállalati jellemzők között ugyanis már kutatásaim kezdetén kitüntetett szerepet szántam a kapcsolati tőkének, melyet érintőlegesen empirikus úton (kérdőíves felmérés keretében) is teszteltem.

Jelen téma megválasztásában persze tudományos munkám mellett, a vállalkozások és a szociológia iránti érdeklődésem is motivált. Ráadásul úgy gondolom, hogy a vállalkozások és vállalatvezetők szociológiai szempontú vizsgálata napjainkban is igen aktuális és időszerü, hiszen éppen a kapcsolati tőke vállalkozásokra gyakorolt hatásának egyre meghatározóbb jellege, mindig tartogat újabb és újabb nyitva hagyott kérdéseket, vizsgálati területeket.

\section{A téma aktualitása, módszertan}

A gazdasági folyamatok alakításában fontos szerepet töltenek be a vállalkozások. A vállalati szféra, azon belül pedig a vállalati elit és a kapcsolati tőke gazdasági, szociológiai szempontú vizsgálata hatással lehet mind a gazdasági fejlödést meghatározó tényezőkre, mind pedig a vállalkozási szerkezetben fellépő problémák kezelésére.

A vállalati elit jellemzőinek feltérképezése, a vállalati elit jellemzői és a gazdasági folyamatok közötti sztochasztikus kapcsolatok elemzése minden időben aktuális a gazdaság egyes szereplőinek, a gazdaság-politika irányvonalát meghatározó szereplőknek, de a téma iránt érdeklődőknek egyaránt. 
Az elemzés során számos hazai és nemzetközi szakirodalom áttekintését végeztem el. Emellett egy általam készített empirikus kutatás (Makszim 2010) is a tanulmány alapjául szolgál. A kvantitatív kutatással kapcsolatban mindenképpen ki szeretném emelni, hogy a mintavétel alapsokaságát képező vállalkozásokat a KSH céginformációs adattárából szürtem le és hoztam létre a kutatás alapsokaságához hozzárendelhető mintavételi keretet.

A kutatás mintavételi technikájának megválasztásakor reprezentativitásra törekedtem. A felmérés során szisztematikus mintavételt alkalmazva 250 vállalkozást, pontosabban vállalatvezetőt kérdeztünk meg személyesen SzabolcsSzatmár-Bereg megye területéről. (A vállalati megkérdezés költségvetési kerete nem tett lehetővé nagyobb mintanagyságot.) Szisztematikus kiválasztás esetén a populáció tagjait bizonyos rendben rögzítjük, és az egyenlő távolságban álló egyedeket választjuk ki (névsor, lajstrom, időközök stb. alapján). Elméletileg ez akkor tekinthető véletlen (valószínüségi) kiválasztásnak, ha a populáció egyedeinek sorba rendezése véletlenszerüen történik (Hunyadi-Mundruczó-Vita 2001 és Falus-Ollé 2008). A felmérés kapcsán ezt úgy biztosítottam, hogy a KSH $\mathrm{ABC}$ sorrendben rögzített - céginformációs adattárából minden 50 . vállalkozást választottam ki. Az információgyüjtés kérdöívvel támogatott, telefonos megkérdezés formájában zajlott, amelyet gyakorlott és erre a célra külön felkészített kérdezőbiztosok végeztek. Az információgyüjtés ideje (2010. június-július) két hónapot vett igénybe négy kérdezőbiztos (köztük jómagam) közremüködésével. A vállalati kérdőívet a 3. számú melléklet tartalmazza. A kérdőív célja az volt, hogy feltérképezze Szabolcs-Szatmár-Bereg megye vállalkozásainak szerkezeti jellemzőit, azok összefüggéseit, illetve gazdasági-társadalmi folyamatokat érintő kapcsolódásait.

A kérdőív egyes kérdései a vállalatok alapadataira vonatkoztak, egy jelentős részük viszont a vállalat tulajdonosainak (vezetőinek) véleményét szerette volna feltárni. Ez utóbbihoz Likert skálát is alkalmaztunk, ahol a válaszadóknak 1-től 5-ig terjedő skálán kellett véleményüket megfogalmazni. Ez utóbbi kérdések föként szubjektív vélemény felderítésére vállalkoztak, ezt a tényt a kapott eredmények értékelésekor figyelembe kell venni. A kérdőívet a kitöltés elött több ízben teszteltem.

A minta megbízhatósági szintje: 95\%, pontossági szintje pedig 6,2 százalékpont, a minta nagysága 250 vállalkozás.

A statisztikai számításokhoz a Windows alapú SPSS 19.0 statisztikai programcsomagot használtam fel. 


\section{Elméleti áttekintés}

Annak érdekében, hogy a jelen tanulmányban megfogalmazott alapvető fogalmak alatt mindenki ugyanazt értse, elengedhetetlen a konceptualizálás, vagyis a kulcsszavak pontos, szabatos definiálása. A témához kapcsolódó szakirodalom oly mértékben szerteágazó és széleskörü, hogy az esszé kereteit lényegesen meghaladó feladat lenne valamennyi területét, akárcsak érintőlegesen is bemutatni. Erre a feladatra nem is vállalkoztam, sokkal inkább a téma fogalmi kereteit biztosító elit, vállalkozó és kapcsolati tőke fogalmak meghatározására, különböző ismérvek szerinti rendszerezésére, csoportosítására. Az irodalomelemzés forrásául a témakör meghatározó és méltán elismert nemzetközi és hazai szakkönyvei, folyóiratokban megjelent szakcikkei és egyéb tudományos művek szolgáltak.

\section{A vállalati elit fogalma}

Az ,elit”, mint társadalmi csoport megjelölésére használt fogalom először a fönemességre és a hadsereg különleges osztagaira vonatkozott. Társadalom- és politikatudományi használata a 19. századtól jellemző, elsősorban Pareto elitszociológiai elmélete nyomán. Pareto munkássága nem áll távol sem a szociológiától, sem pedig a közgazdaságtudományoktól, így - mivel e két tudományterület jelen tanulmányban is összekapcsolódik - számomra ő jelent egyfajta kiindulópontot a módszertani alapok területén.

Pareto társadalmi elitértelmezése összefügg a szó eredeti jelentéstartalmával: nemcsak az áruk között vannak kiválóak, hanem az emberek között is. Ezek körét egzakt módon, úgy határozta meg, hogy minden ember tevékenységéhez egy indexet rendelt. Az elit osztályát pedig azokból alakította ki, akiknek a legmagasabb indexszámuk van az adott ágazatban (Pareto 1972). Ennek eredményeképpen két részre bontotta ezt az osztályt:

- kormányzó elit: akik közvetlen vagy közvetett módon jelentős szerepet játszanak a kormányzásban, így például a miniszter, a szenátor, a bírósági elnök, az ezredes stb.; a többiek pedig a

- nem kormányzó elitet képezik.

Ma már úgy gondolom, problémás lenne a vállalatvezetők egyetlen index alapján történő minősítése, mivel nehéz pontosan behatárolni azokat az ismérveket, amelyek a jó vezető kritériumaként szolgálhatnak. A minősítés alapjául szolgáló változók száma nem is határozható meg pontosan, számuk fokozatosan bővül, tartalmilag átalakul, ráadásul egyre több változó bevonása egy elméleti indexbe egyre kevésbé teszi lehetővé az általános következtetések levonását. Emellett 
persze Pareto jelentősége vitathatatlan az elitkutatásokban, így többek között nagy hatással volt a neoelitista irányzatok közül Lasswell munkásságára, aki Paretohoz hasonlóan értelmezte az elit fogalmát: azok a személyek, akik az értékből a legtöbbet tudhatnak magukénak (Lasswell 1934). Később az elit fogalmát ő már kizárólag a politikai elittel azonosította, és eltekintett annak gazdasági, társadalmi vetületeitől.

A 20. század közepétől a politikai elit mellett fokozatosan megjelent a gazdasági elit fogalma, amely a gazdasági hatalomhoz, a gazdasági pozíciókhoz vagy a gazdasági életben megnyilvánuló különleges karaktervonásokhoz köthető. Szükebb értelmezésben a gazdasági elit csupán a nagyvállalatok vezetőit képezi (Róna-Tas-Böröcz 1997). Ezt a szükebb értelmezést vettem alapul a tanulmányban megjelenő empirikus kutatás során is, hiszen a kérdőív egyes kérdései kifejezetten vállalatvezetőkhöz lettek címezve, és ők maguk adtak választ rájuk.

A gazdasági elit fogalma kapcsán elsősorban James Burnham (1965) munkásságát kell kiemelni, aki a „menedzserek forradalmának” elméletében e fogalom részletes tartalmát tárta fel. Burnham megkülönbözteti a kapitalista és a menedzseri társadalmat. Ez utóbbiban már nem a tulajdonosok, hanem a menedzserek irányítják és ellenőrzik a termelést. A „menedzserek forradalma” kifejezés arra utal, hogy a gazdasági döntéshozók köre változott meg. Burnham ugyanakkor a gazdasági elit vizsgálatakor a személyes jellemvonások jelentőségére irányítja a figyelmet. A menedzsereket két csoportra osztja: egyrészt a tudósok és technokraták csoportjára, másrészt a vezetőkre és a termelési folyamat koordinátoraira. Mindkét csoportba olyan személyek fognak kerülni, akik alkalmasak az adott feladatra, tehát a gazdaság önmaga termeli ki a saját elitjét. Így a személyes jellemvonásaik és képességeik alapján legmegfelelőbb emberek kerülnek a fö gazdasági döntéshozói pozíciókba.

Jelen tanulmányban a menedzseri társadalom csak szük körben jelenik meg, hiszen a menedzser réteg a nagy-, vagy esetleg a középvállalatokhoz kötődik, míg az általam végzett kutatásban a mikro-és kisvállalkozások dominálnak, melyekben jellemzően a tulajdonos egyben a vállalat vezetője is. A magyar vállalati szférában egyébként még mindig igen szük réteget képeznek a menedzserek, melynek egyértelmüen a tőkeszegénység az oka, ami által nem tud kialakulni egy szélesebb nagyvállalati kör, ezáltal egy versenyző menedzser réteg.

Bendix és Howton (1967) felsorolja a gazdasági elit fogalomkörét betöltő személy legfontosabb karakterjegyeit: a presztízs, a jövedelem, a társadalmi és politikai befolyás, az adott cég nagysága és sikeressége, a kapcsolatháló kiterjedtsége, az alárendeltek száma, a civil szférában kifejtett aktivitás stb. A felsorolásból kitünik, hogy már e szerzőpáros is fontosnak tartotta a kapcsolati tőke, „kapcsolati háló” szerepét a gazdasági elit értelmezésében. A jellemzők sokasága azonban nem teszi lehetővé az általánosítható következtetések levonását. 
Bourdieu (1998) definíciója az elitről már konkrétabb, melynek meghatározásakor tőkeelméleteiből indul ki, és azt mondja, hogy azok tartoznak a társadalom domináns csoportjaiba, akik a legtöbb tőkefajtával rendelkeznek. A tőkének több fajtáját különböztette meg: szociális, gazdasági, társadalmi és kulturális tőkét. Bourdieu munkássága tehát rendkívül közel áll dolgozatom témájához, hiszen elméleteiben szintén összekapcsolódik az elit és a kapcsolati tőke, pontosabban utóbbi nála még társadalmi tőke.

Hasonlóan közelálló módszertani alapokat nyújtott Róna-Tas Ákos és Böröcz József (1997) megközelítése is, akik abból az elméleti állításból indultak ki, hogy a gazdasági elitek kialakulását mind az államszocialista időszakban, mind pedig az azt megelőző korban gyökerező gondolkodásmód, szaktudás és kapcsolatrendszer befolyásolja. Ezek a társadalmi jellemzők tipikusan az egyes egyénhez tapadó, nagy tehetetlenségü erőforrások. A mentalitás, a szaktudás és a kapcsolatrendszer azért tapadósak, mert nem könnyü megszabadulni tölük vagy másoknak átadni őket. Még nehezebb erőszakkal elvenni őket az emberektől. Ezeket a nem anyagi jellegü erőforrásokat kizárólag az őket birtokló egyének képesek megváltoztatni. Ezt a jelenséget elméletükben az individuum oszthatatlanságának nevezik. Minden embernek megvan a maga mentalitása, szaktudása és kapcsolatrendszere, és nagyon nehéz megváltoztatni ezeket a jellemzőket, mert kialakulásukat egy egész életpálya határozza meg. Ebből következik, hogy ezeknek az adottságoknak az ereje az idő függvénye, s így hosszú idő kell a kialakulásukhoz, de éppen ezért a megváltoztatásuk is igen nehéz. Az intézményi és a társadalmi változásban betöltött szerepük megértéséhez nem elég a személyes adottságok önmagában való vizsgálata, hanem azt is fel kell tárni, hogy hogyan alakulnak ki és változnak meg ezek az adottságok, és milyen hatással vannak a gazdasági és társadalmi folyamatokra. Kutatásomat elsősorban ez utóbbi (Róna-Tas és Böröcz 1997) elméleti megközelítésre építettem, ezt a gondolatmenetet próbáltam meg továbbvinni, és igazolni empirikus adatok és elemzések segítségével.

\section{A vállalkozó, mint a vállalati elit meghatározó személye}

Hasonlóan sokszínú a vállalkozó fogalmi lehatárolása is, melynek egyik korai definícióját Cantillon adta a XVIII. század elején, aki mint racionális döntéshozót jellemezte a vállalkozót, aki kockázatot vállal és menedzsmentet biztosít az üzlet számára. A kereslet és a kínálat egyensúlytalanságából adódó lehetőségeket kihasználva célja a profitszerzés. A középkori vállalkozó-felfogással szemben, amikor is a vállalkozó csupán a nagy termelőmunkák irányításáert felelt, Cantillon korai vállalkozó elméletében központi szerepet kapott a kockázatvállalás (Herbert és Link 1982).

A XVIII. század folyamán kitágult a vállalkozó értelmezése, melynek következtében elkülönült egymástól a kockázatot viselő személy és a tőkét biztosító személy, megteremtve ezzel a kockázati tőkés fogalmát. A XIX. század végén a 
vállalkozó és a menedzser személye szorosan összefonódott, a vállalkozó az erőforrások hatékony müködtetőjeként jelent meg, aki nyereség elérésére törekszik. Ahogyan arra már korábban is utaltam jelen tanulmány kérdőíves felmérése is döntö mértékben olyan vállalkozásokat tartalmaz, ahol a tulajdonos egyben menedzser is. A mikro- és kisvállalkozások ugyanis nem engedhetik meg maguknak, hogy e két szerep külön váljon.

A XX. század közepétől az újítás jelent meg a vállalkozás alapvető jellemzöjeként (Schumpeter 1980). A vállalkozó, mint újító fogalom összefonódott Schumpeter munkásságával, aki mellesleg a közgazdaságtan és a statisztika területén egyaránt otthonosan mozgott. Míg Cantillonnál a vállalkozó kihasználja az egyensúlytalanságból adódó lehetőségeket, addig Schumpeternél maga a vállalkozó egy aktív, egyensúlytalanságot teremtő erö, aki mint kiváló innovátor változásokat vezet be, lerombolja a fennálló egyensúlyi helyzetet. Így Schumpeter felfogásában a vállalkozás szorosan összekapcsolódik a gazdasági növekedéssel. Vállalkozó definíciójában viszont - sokakkal ellentétben - ő nem emeli ki a kockázatvállalási szerepet. Schumpeternél tehát az újitás áll a középpontban, elősegítve ezzel a gazdaság fejlődését.

A schumpeteri vállalkozó fogalmához áll közel a következő megközelítés is: szükebb értelemben vállalkozónak tekintjük azokat, akik vállalkozásuk során saját vagyonukat kockáztatva aktív szerepet játszanak az üzletmenet irányításában. A menedzserek, vállalatvezetők ugyan fontos szereplői a vállalkozásoknak, de nem vállalkozók, amennyiben befektetett vagyonukkal nem viselik a döntések kockázatát (Kállay et al. 2004). E definíció alapján leginkább csak az önfoglalkoztatók, a mikrovállalkozások férnének bele a vállalkozó fogalmába. Ez a megközelítés így nem alkalmazható egységesen a vállalkozó fogalmára.

Hisrich és Peters (1991) szerint a vállalkozó eredetileg „közvetítő" vagy „kapcsolatteremtőt” jelent. Vecsenyei (2002) így ír a vállalkozóról: „az a személy, aki a káoszban felismeri a lehetőséget, aki a semmiből akar létrehozni valami értéket, aki egyedül vagy másokkal együttmüködve valósítja meg termékben, szolgáltatásban, szervezetben megnyilvánuló elképzeléseit.” Az általam használt vállalkozó fogalma Hisrich és Peters, illetve Vecsenyei értelmezéséhez áll a legközelebb, hiszen mindegyikük kiemeli a kapcsolat, az együttmüködés jelentőségét a vállalkozó meghatározása során. Véleményem szerint a vállalkozó értelmezhető úgy is, mint aki a vállalati szerkezeti jellemzőknek és a területi fejlődést meghatározó gazdasági-társadalmi folyamatoknak egymással összefüggő és egymással kapcsolatban lévő rendszerét koordinálja.

A vállalkozó fogalmát még aprólékosabban elemezhetjük, ha bevonjuk a vizsgálatba a gazdasági jellemzők mellett a nem gazdasági a személyiségjegyeket is. Sokak szerint vállalkozónak születni kell, mások szerint ez is, csakúgy, mint sok más dolog az életben tanulható. 
A vállalkozó nem gazdasági magyarázatára először Max Weber tett kísérletet, összekapcsolva a modern kapitalizmus fejlődését a „protestáns erkölcs” terjesztésével. Véleménye szerint a vállalkozói jellemvonások külső eredetü vallásos hiedelmek hatására jönnek létre (Fülöp 2004).

Kilby (1971) mutat rá arra, hogy a pszichológiai elméletek feltételezik, hogy a vállalkozók veleszületett személyiségjegyekkel jellemezhetők, és sajátos motivációkkal rendelkeznek. A sikeres vállalkozókra önbizalom, tudatosság, reális környezetszemlélet, kiváló koncepcióalkotó képesség, jó kapcsolatteremtő képesség, jó egészségi állapot jellemző. A vállalkozók fontos jellemvonásai még a belső energia, a személyes varázs, az önuralom a jó kommunikációs készség. Az eddig említetteken túl számos szerzőnél olyan jellemzők is megjelennek, mint az érzelmi stabilitás, az önfeláldozás vagy a munkájuk iránti megszállottság (Bygreve 1997).

Fülöp és Szegedi (Fülöp 2004) kutatásai alapján megállapítható, hogy a vállalkozási tevékenységek, illetve döntéssorozat középpontjában leginkább az öröklött készségek, a fejleszthető képességek és a megmaradt ismeretek állnak.

A kutatás súlypontja az utóbbi időben egyértelmúen a vállalkozó és a gazdasági fejlődés összefüggéseinek feltárására, valamint a vállalkozó nem gazdasági (elsősorban szociológiai, pszichológiai) szempontú jellemzőinek vizsgálatára tevődött át. Az új irányvonalak között (Nijkamp, Capello, Florida) megjelenik az általam is elemzett kapcsolati tőke hatásainak elemzése a vállalati szférában, valamint a gazdasági, társadalmi folyamatokban. Ezek részletes feltárása jövőbeli kutatási céljaim között szerepel.

A vállalkozókat több szempont szerint csoportosíthatjuk, melyek közül a legjellemzőbbeket az 1. számú melléklet emeli ki.

\section{A kapcsolati tőke fogalmi lehatárolása}

A kapcsolati tőke fogalma meglehetősen összetett tartalommal bír, így egységes definiálásáról máig sem beszélhetünk. Többféle megközelítés létezik, melyek döntő része a kapcsolati tőkét a társadalmi tőke részleges alternatívájának tekinti (ld. Putman, Coleman, Bourdieu, Fukuyama, Lin, Burt). A társadalmi tőke olyan magánvagyon, amely erősítheti az érintettek társadalmi státusát, hatalmát (Bourdieu, 1998).

A kapcsolati tőke tartalmát tekintve megfelel a tőke közgazdaságtani definíciójának, hiszen a kapcsolati tőke alkalmas termékek és szolgáltatások létrehozására, miközben maga nem alakul át, illetve a kapcsolati tőke előállításához a majdani haszon reményében áldozatot kell hozni.

A kapcsolati tőke Becker (1996) elméletében az egyéni haszonmaximalizálás tárgya.

Bosma (2002) érvelésének lényege az, hogy a kapcsolati tőke az emberi tőkéhez hasonlóan szignifikánsan növeli a vállalkozás teljesítményét és a vállalko- 
zás sikerének esélyét. Egyfelől, mert a jobban müködő szervezet növeli a munkaerő termelékenységét, másfelöl a jelzés-hatás miatt, vagyis a több emberi és kapcsolati tőke jó képet fest a cégről, annak potenciális teljesítményéről, a cégről keveset tudó gazdasági szereplők számára.

Hofferth és társai (1999) szerint akkor beszélhetünk kapcsolati tőkéről, ha a korábbi beruházások és a későbbi profit között erős és pozitív összefüggés mutatható ki.

Lin (2001) szerint a kapcsolati tőke olcsóbbá és megbízhatóbbá teszi az információ-áramlást, csökkenti a vállalatok megkeresésének tranzakciós költségeit, növeli a vállalatok hírnevét, önbizalmát.

Fafchamps és Minten (2002) szerint a tökéletlenül müködő piac feltételei között a kapcsolati tőke hasznossága azt jelenti, hogy mások ismeretéből haszna származik a vállalkozónak. A kapcsolatok segíthetik a vállalkozót abban, hogy

- olcsó és megbízható információhoz jusson,

- a másokkal kötött megállapodásai teljesüljenek,

- a kapcsolati tőke a kartellképzés, az oligopólium létrehozásának is lehet eszköze.

Galasi (1994) szerint a kapcsolati tőke a vevőkkel, ügyfelekkel illetve egyéb külső partnerekkel kialakított kapcsolatokat tartalmazza. A kapcsolati tőke a szervezet sajátja, bár a szervezet tagjai hozzák létre, de ezek hosszú időn keresztül fennmaradnak és személyfüggetlenné válnak. A kapcsolati tőke helyét a vállalkozások tőkerendszerében az 2. számú melléklet mutatja be.

A Galasi-féle vállalati tőkestruktúrát azzal a megállapítással szeretném kiegészíteni, hogy a pénzügyi és az intellektuális tőke mellett a fizikai tőke is ugyanolyan fontossággal bír, így ez utóbbi elem is a vállalati tökeállomány önálló elemeként értelmezhető.

Látható, hogy a kapcsolati tőkét nem lehet egyértelmüen definiálni, nincs is egységes fogalma. Ez azonban nem feltétlenül probléma, hiszen a kapcsolati tőke egy rendkívül összetett jelenség, és valójában valamennyi előbb említett meghatározás része e fogalom komplex értelmezésének. Éppen ezért nem mondhatjuk egyik vagy másik meghatározásra, hogy jó vagy rossz, helyes vagy helytelen, hanem célszerü valamennyi megközelítést figyelembe venni, és komplexen, az aktuális gazdasági, társadalmi jelenségek tükrében elemezni a kapcsolati tőkét és befolyásoló szerepét.

\section{A kapcsolati tőke és a vállalat viszonya}

A kapcsolati tőke a gazdasági kapcsolatok koordinálását végzi el a piac mellett, azaz kizárólag a piac nem képes minden mechanizmust koordinálni. Ez az össze- 
függés egyúttal rávilágít a piac és a vállalat egymáshoz való viszonyának problémájára. A kapcsolati tőke egyrészt feltételezi a piac jelenlétét, hiszen a piac szabályozza azt, hogy mások képességeihez hozzáférjünk, a kapcsolati töke pedig összeköti a gazdasági élet szereplöit.

A kapcsolati tőke megszerzése, vállalati szintủ adaptálása a technikai újdonságokhoz hasonlóan szintén a gazdasági növekedés irányába ható folyamatokat indít el.

Feltételezem, hogy a kapcsolati tőkének költsége van, amely a korlátozott racionalitás tényét erősíti. Minden egyes vállalat olyan kapcsolati tőkét hordoz, amely lényegesen különbözik a többi vállalat kapcsolati tőkéjétől, azaz a kapcsolati tőke vállalatspecifikus. A kapcsolati tőke jelentősen meghatározza a vállalatok heterogenitását. Ebböl következik, hogy a vállalatok ugyanazon tevékenység végzésénél is lényegesen eltérő kapcsolatokkal rendelkeznek. Ennek oka, hogy a kapcsolati tőke hallgatólagos és szétszórt a vállalatok között, így a kapcsolati tőke koordinációját a vállalatok különböző módon oldják meg. A vállalat tehát azért tesz belsővé egy tevékenységet, mert azt a kapcsolati tőke tekintetében hatékonyabban tudja megszervezni, mint a piac. Végső soron a vállalat kapcsolati tőkéje szerepet játszik abban, hogy mit tud a vállalat a piaci transzfer költségek csökkentésével a piac közvetítése nélkül hatékonyabban megtenni.

A kapcsolati töke több síkon is determinálja a vállalat által belsővé tett tranzakciók körét, azok hatékonyságát, eredményességét, sőt árát is:

$>$ Időtényező: mind rövid, mind pedig hosszú távon a vállalati múltnak nagy szerepe van a vállalat további lehetőségei terén, azaz a korábbi kapcsolati tőke meghatározza a vállalat jövőbeli lehetőségeit, közvetetten az adott térség fejlődését.

> Transzferálhatóság: korábban megállapítottam, hogy a kapcsolati tőke vállalatspecifikus, így legfeljebb csak magas költségekkel (elsősorban a kommunikációs költségek miatt) adható át más vállalatoknak. A kapcsolati tőke transzferálhatóságának magas költségei miatt hatékony megoldás lehet a horizontális vagy a vertikális integráció, amely hatással lehet a területi folyamatok nivellálódására is. Az integráció alapvetően a kapcsolati tőke nehezen átadható, nehezen közvetíthetö, specifikus, nem szerződhető jellegéből következik.

> Terjedés: a kapcsolati tőke terjedésének fontos eszköze a hatékony információs rendszer.

$>$ Összességében a kapcsolati tőke egyszerre adhat magyarázatot a hatékonyság kérdésére, illetve a környezet gazdasági változásainak kihívásaira. A kapcsolati tőke olyan erőforrás, amely nem lehet piaci tranzakció tárgya, így tartós versenyelönyt biztosíthat a vállalat és környezete számára egyaránt (Makszim 2011). 


\section{A kapcsolati tőke és a vállalat belső szervezete}

A kapcsolati tőke hatása a vállalat belső szervezetére három lényeges területet érint: a koordinációs mechanizmusokat, az ösztönzési rendszert, és a kognitív mechanizmusokat. E három terület vizsgálata részben gazdasági, részben pedig szociológiai szempontokat vet fel.

A bizonytalan, változó környezetben a kapcsolati tőke szerepét, hatásait a szervezet tagjai különbözőképpen értelmezik, ezért a szervezetben lennie kell olyan mechanizmusnak, amely ezeket megoldja. Ezt a feladatot a koordináció látja el. A koordinációs probléma azért is kerül a középpontba, mert nemcsak a kapcsolati töke megszerzése tökéletlen, hanem ezek integrálása és vállalati szintủ leképezése is. A gyorsan változó környezet ugyanis feltételezi a szervezeti koordinációt, még akkor is, ha minden egyén teljes mértékben azonosul a szervezeti célokkal. Az ösztönzési rendszernek olyannak kell lenni, amely ráveszi az ágenseket a kapcsolati tőke megszerzésére és a vállalati szervezetbe való adaptálására. Ez a fajta motiváció egyértelmüen a korlátozott racionalitást hívja életre. A megfelelö ösztönzési rendszer kialakítása életre hívja a vállalatvezető szerepének beépítését a rendszerbe. Végső soron olyan irányítási rendszerre van szükség, amely képes koordinálni és a vállalat müködésébe építeni a kapcsolati tőkét. Ennek fontos eszköze a hatékony információs rendszer, mint közös tudásbázis.

A kognitív mechanizmusok szorosan kötődnek a vezetői kompetenciákhoz, ami véleményem szerint azzal indokolható, hogy a kapcsolati tőke szoros összefüggésbe hozható a vezetői hozzáértéssel, képességekkel. A vállalat méretének növekedésével egyre több kapcsolati tőkét kell integrálni és adaptálni, ami pozitív, erős korrelációt mutat a vezetői kompetenciákkal. A vezetői kompetenciák növekedésével nő a kapcsolati tőke megszerzésének esélye.

A kapcsolati tőke megszerzésében és koordinálásában a vállalkozást irányító személy, mint a vállalati elit tagja tölti be a legfontosabb szerepet.

\section{A kapcsolati tőke sajátosságai}

Kutatásom során megállapítottam, hogy szükösnek kell tekinteni az eleve adott kapcsolati tőkét, azaz az újabb kapcsolati tőke megszerzésére való képességet. Hangsúlyozni kell, hogy a vállalat nem eredendően áll a piac felett, csak bizonyos szituációkban képes olcsóbban megszerezni és adaptálni azt a kapcsolati 
tőkét, amelynek mérhetősége bizonytalan ${ }^{1}$. Ez azt jelenti, hogy a kapcsolati tőke mértékének és szerkezetének időbeli és országok közötti összehasonlítása megbízhatatlan, és az így kapott adatok aggregálhatósága is erősen korlátozott. További problémát jelent, hogy a kapcsolati tőke kultúrafüggő, nem könnyen mobilizálható, létrehozása időigényes, illetve erősen függ mások kapcsolati tőkéjének mennyiségétől.

A kapcsolati tőke az elidegeníthetőség szempontjából is speciális, hiszen nincs egyetlen és kizárólagos tulajdonosa. Emellett központi nyilvántartása a többi tőkéhez hasonlóan nehezebben megvalósítható, de különböző hálózatelemzési technikákkal (pl. az interneten keresztül) ma már egyre több ilyen jellegü törekvés létezik. A kapcsolati tőke formalizált elemeit (amelyek pl. szerződések formájában is megjelennek) komoly vállalkozások vezetői információs rendszerük részeként is nyilván tartják és rendszeresen felülvizsgálják, így ezek az objektív módon megjelenő elemek - amennyiben nem titkosak feltérképezhetők. A nem formalizált, szubjektív elemek ilyen jellegü összegyüjtése azonban csak indirekt módon lehetséges, de a versenytársak várható lépéseinek kiszámítása érdekében - ha korlátozottan is -, de számon szokták tartani vállalkozói körökben.

Tartósság szempontjából a kapcsolati tőke a többi tőkétől eltérően viselkedik, ugyanis értéke a használat során nem amortizálódik, hanem még nőhet is. A kapcsolati tőkének van egy anyagi tőkepótló ereje is. Azt azonban, hogy hogyan kompenzál a vállalatok müködésében (pl. tovább müködnek), egyáltalán kompenzál-e, és hogyan fejti ki hatását a területi folyamatokra, statisztikailag nem mérhető. Jelenlétével és gazdasági folyamatokat befolyásoló erejével azonban mindenképpen számolni kell. A kapcsolati tőke szociológiai szempontú értelmezése tehát semmiképpen sem hagyható figyelmen kívül - így a barátság, a kölcsönös függőség, a korrupció részletes elemzése további vizsgálataink tárgyát képezi a jövőben.

\section{A kapcsolati tőke vizsgálata empirikus kutatás alapján}

A kapcsolati tőke fogalmilag, mint személyes kapcsolatrendszer jelenik meg a kérdőíves felmérés (ld. 3. számú melléklet) 10. kérdésében: Értékelje 1-5-ig terjedő skálán, hogy a munkatársak tekintetében milyen kompetenciák fontosak

\footnotetext{
${ }^{1}$ A kapcsolati tőke mérhetősége matematikai értelemben nem lehetséges, esetleg minőségi kategóriák mentén biztosítható az összehasonlítás lehetősége.
} 
vállalkozása számára (nyelvtudás, személyes kapcsolatrendszer, kommunikációs készség, problémamegoldó készség, szakmai gyakorlat, informatikai ismeretek, külső megjelenés, szakmai képzés során megszerzett tudás)! 5 legyen a legfontosabb!

A témához kapcsolódóan a zárójelben felsorolt kompetenciák közül a hangsúlyt, a személyes kapcsolatrendszerre szeretném helyezni a következőkben. Előzetes feltételezésem szerint a kapcsolati tőke meghatározza a vállalkozások alapvető strukturális jellemzőinek alakulását, végső soron a vállalkozások fejlettségét.

A személyes kapcsolatrendszer fontosságának megoszlása 1-5-ig terjedő skálán

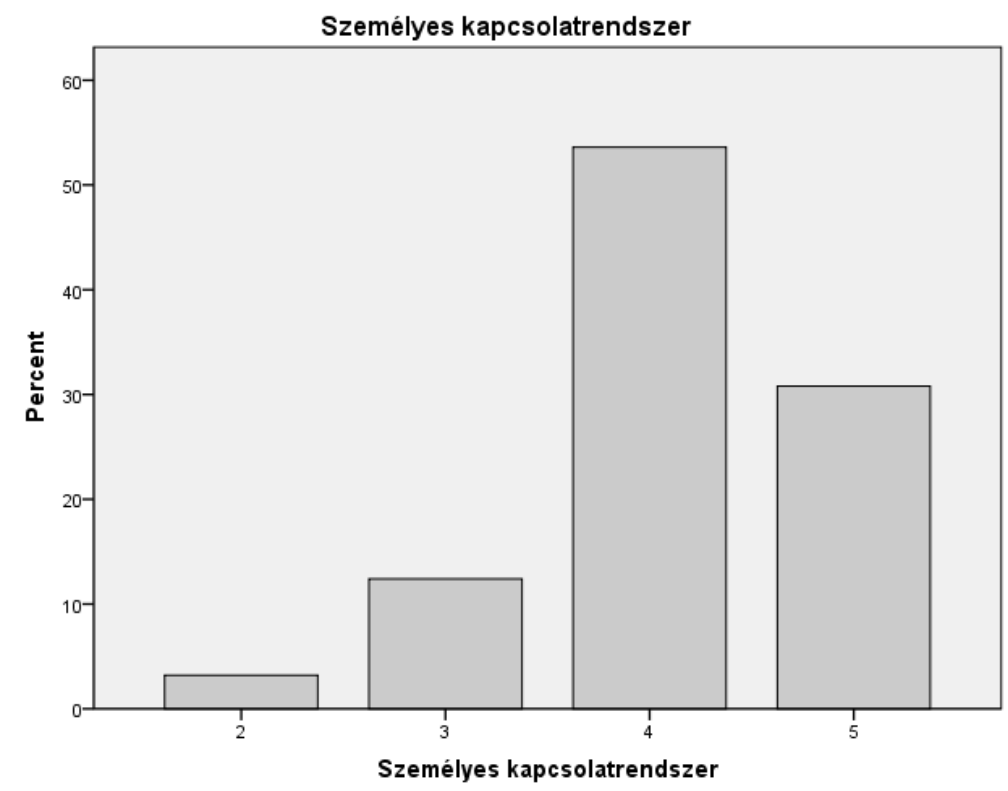

Forrás: Saját kutatás

A 250 megkérdezett vállalkozó többsége (54\%-a) négyesre, 31\%-a ötösre, 12\%a közepesre, míg 3\%-a kettesre értékelte a kapcsolati tőke fontosságát.

Elemzéseim során sztochasztikus kapcsolatok (az esszéhez kapcsolódóan asszociációs- és vegyes kapcsolatok) számítását végeztem el a személyes kapcsolatrendszer és a vállalkozások valamennyi kérdőívben szereplő kvalitatív és kvantitatív ismérvei között. Az egyes valószínüségi kapcsolatok megértése szempontjából - a 10. kérdésen túl - azonban röviden szeretném bemutatni a kérdőíves felmérés további elemeit is, kiemelve legfontosabb kutatási eredményeimet, és a jelen témához kapcsolódó következtetéseimet. 
A kérdőíves felmérés során elsősorban arra kerestem választ, hogy hogyan alakulnak a Szabolcs-Szatmár-Bereg megyei vállalkozások szerkezeti jellemzői (tevékenységi kör, gazdálkodási forma, méret stb.), és milyen szerepet vállalnak a megye vállalkozásai a gazdasági élet dinamizálásában $(\mathrm{K}+\mathrm{F}$, exporttevékenység, foglalkoztatás, oktatással való kapcsolat). Vizsgáltam, hogy van-e kimutatható összefüggés a vállalkozások szerkezeti jellemzői között, illetve az összefüggések milyen hatással lehetnek az adott térség gazdasági helyzetére, fejlettségére.

Mikro-szinten a vállalkozások müködését, tevékenységét, gazdasági szerepvállalási képességét befolyásoló szerkezeti, strukturális jellemzőket vontam be vizsgálataimba, melyeket kvantitatív és kvalitatív csoportba soroltam a következők szerint:

- Kvantitatív befolyásoló tényezők:

- alapítás éve,

- éves nettó árbevétel,

- foglalkoztatottak száma,

- mérlegföösszeg.

- Kvalitatív befolyásoló tényezők:

- tevékenységi kör,

- gazdálkodási forma,

- tulajdoni viszony,

- exporttevékenység,

- kutatás-fejlesztési tevékenység,

- dolgozói kompetenciák,

- a vállalkozás jövőre vonatkozó foglalkoztatási tervei,

- szakmai gyakorlat biztosítása,

- kapcsolati tőke.

A kérdőíves felmérés 1 . kérdése az ágazati szerkezet megoszlására vonatkozott, mely szerint a mintát alkotó Szabolcs-Szatmár-Bereg megyei vállalkozások között jelentős a kereskedelemben $(21,2 \%)$ és a pénzügyi szolgáltatások (20,8\%) területén tevékenykedők aránya, ezt követi (10,8\%-kal) az ipar szektora. A többi ágazat aránya ugyan nem éri el a 10\%-ot, de közülük még mindig meghatározó a szállításban és hírközlésben $(8,8 \%)$, valamint a mezőgazdaságban $(8,8 \%)$ tevékenykedő vállalkozások súlya. 
A mintabeli vállalkozások nemzetgazdasági ág szerinti megoszlása

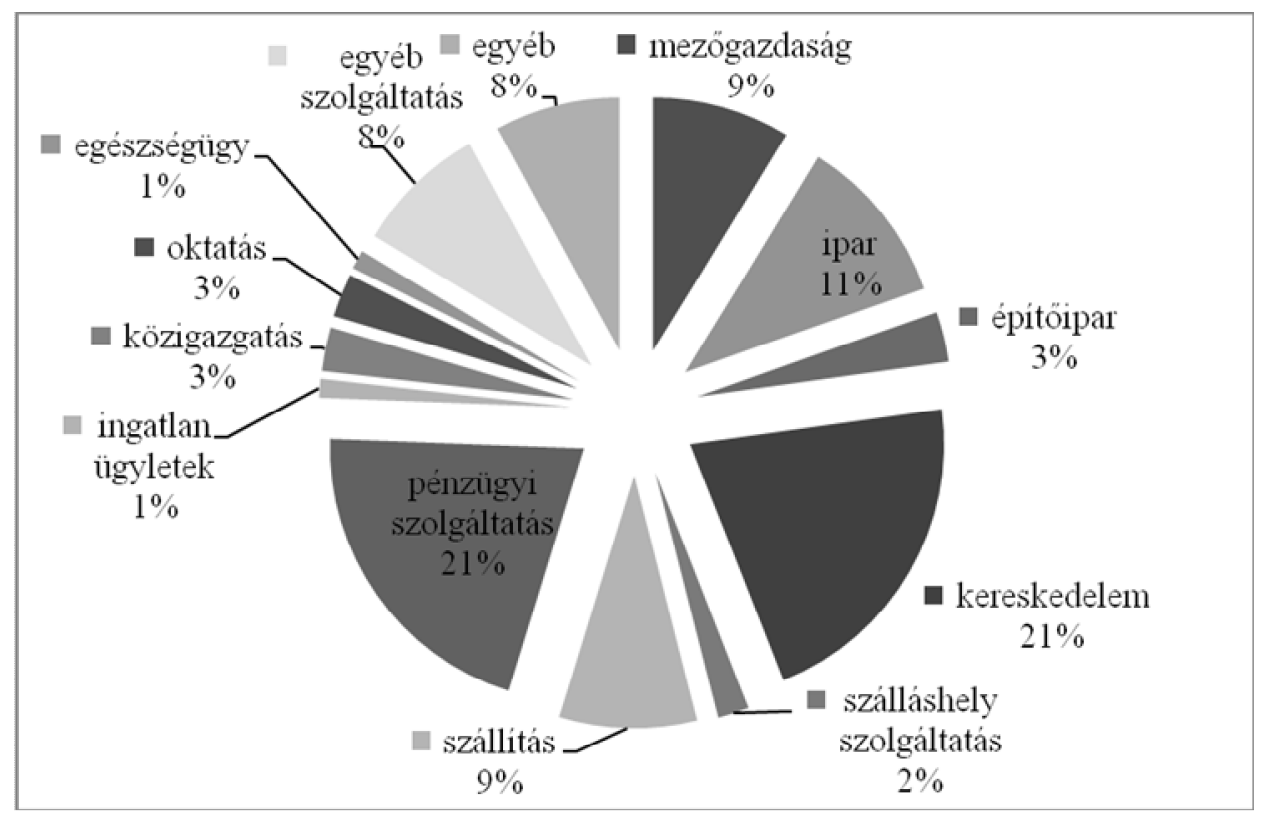

Forrás: Saját kutatás

Szabolcs-Szatmár-Bereg megyében tehát a „hagyományosabb” (tényleges, anyagi átalakító tevékenységet folytató) szektorok töltenek be domináns szerepet, és a megye nehezen tud elszakadni alapvetően agrár jellegétől. Ez azonban nem feltétlenül probléma, hiszen a jövőben éppen a meglévő tradicionális iparágak minőségi kiszolgálására lehetne építeni.

Ezek alapján szignifikáns, közepesen erős a kapcsolat az ágazat és a személyes kapcsolatrendszer között, melyet a szórás hányados mutató: $\mathrm{H}^{2}=0,47$ értékkel jelez. A személyes kapcsolatrendszer egyébként az ingatlanügyletek, valamint a pénzügyi szolgáltatások területén bizonyult a legfontosabb kompetenciának.

A vállalkozások gazdálkodási forma szerinti vizsgálata (2. kérdés) során megállapítottam, hogy a mintabeli vállalkozások többsége, mintegy 62\%-a egyéni vállalkozásként folytatja tevékenységét, $36 \%$ a társas vállalkozások ará-

${ }^{2}$ A vegyes kapcsolat szorosságának PRE-mutatója, amit H-val jelölünk: a variancia-
hányados, ami a külső szórásnégyzet és a teljes szórásnégyzet hányadosából vont négyzetgyök érték. $\mathrm{H}=\sqrt{\frac{S S K}{S S T}}=\sqrt{\frac{\sigma_{\mathrm{K}}^{2}}{\sigma^{2}}}$ (Hunyadi-Mundruczó-Vita, 2001) 
nya és mindössze $2 \%$ az egyéb szervezeteké. A társas vállalkozások $98 \%$-a gazdasági társaság, 2\%-a pedig szövetkezet. A gazdasági társaságokon belül a jogi személyiséggel nem rendelkezők között a betéti társaságok (86\%), míg a jogi személyiséggel bírók között a korlátolt felelősségü társaságok (79\%) dominálnak. Elöbbi (bt.) a mintabeli összes vállalkozás 18\%-át, utóbbi (kft.) pedig a $12 \%$-át teszi ki. A közkereseti társaságok és a részvénytársaságok aránya nem éri el az 5\%-ot.

A vezetöi kompetenciák tekintetében a személyes kapcsolatrendszer a részvénytársaságok körében nagyon jelentős kompetenciának bizonyult, ami arra enged következtetni, hogy a vállalat mérete, tőkeereje szoros összefüggésben áll az adott vállalat kapcsolatrendszerével.

Az alapítás éve (3. kérdés) egyetlen vállalati jellemzővel sem áll statisztikailag kimutatható kapcsolatban a minta esetén.

A 4. kérdés az árbevétel vizsgálatára terjedt ki, melynek eredményei: mintát alkotó vállalkozások túlnyomó többsége, 94,4\%-a, 2 millió eurónál alacsonyabb nettó árbevétellel rendelkezik, 4,8\%-a 2 és 10 millió euró közötti árbevétellel és mindössze $0,4-0,4 \%$-ot képeznek azok a vállalkozások, amelyek $10-50$ vagy 50 millió euró fölötti árbevételt realizáltak 2009-ben. Az alkalmazotti kompetenciák nincsenek statisztikailag kimutatható kapcsolatban a nettó árbevétellel. Ennek oka adódhat egyrészt abból, hogy az árbevétel alakulását sokkal inkább meghatározza az exportteljesítmény és az innováció, másrészt a kapcsolat hiánya magyarázható a kapcsolati tőke hallgatólagos jellegével. Aligha képzelhető el ugyanis olyan vállalkozó, aki vállalkozása üzleti sikerét elsősorban üzleti kapcsolataival magyarázná saját belső képességei helyett.

Az 5. kérdés a Szabolcs-Szatmár-Bereg megyei vállalkozások foglalkoztatotti létszámára, 6. pedig mérlegföösszegére vonatkozott. A vállalkozások többsége (85,6\%-a) 50 fônél kevesebb foglalkoztatottal rendelkező mikro- és kisvállalkozás, 4,8\%-uk 50-249 fös középvállalkozás és 9,6\%-uk 250 fö fölött foglalkoztató nagyvállalat. A személyes kapcsolatrendszer ugyan nincs szignifikáns kapcsolatban a létszámmal, az azonban a minta alapján megállapítható, hogy a kapcsolati tőke a nagyvállalatok esetén sokkal fontosabb vezetői/vállalati kompetencia, mint a kisvállalkozások tekintetében.

A mintában a vállalkozások 88\%-a 2 millió eurónál kevesebb, 12\%-a pedig ennél nagyobb mérlegföösszeggel rendelkezik. Az átlagos mérlegföösszeg 2,3 millió euró, amit jóval meghalad a szórás, 5,7 millió euróval. A személyes kapcsolat rendszer nem hozható statisztikailag összefüggésbe a mérlegföösszeggel.

A tulajdonosi szerkezet elemzése (7. kérdés) alapján megállapítható, hogy a minta vállalkozásainak többsége, mintegy $75 \%$-a 100\%-ban magyar tulajdonban van, kisebb arányt (12\%-ot) képviselnek a 100\%-ban külföldi tulajdonban lévők, továbbá $7 \%$-ot az $50 \%$ feletti magyar és $6 \%$-ot az $50 \%$ feletti külföldi tulajdonú 
vállalkozások. A tulajdoni struktúra és a kapcsolati tőke között nem mutatható ki szignifikáns összefüggés.

Ezzel szemben a személyes kapcsolatrendszer szoros összefüggésbe hozható az adott vállalkozás exportteljesítményével (8. kérdés alapján): e kompetencia nagyobb súlya az exporttevékenységet folytató vállalkozások esetén kiemelkedő, míg az exportot nem végzők körében jelentőségük lényegesen kisebb, ami a kapcsolati tőke piacbefolyásoló erejét tükrözi.

A kérdőíves felmérés 9. kérdése a kutatás-fejlesztés vizsgálatára terjedt ki. A mintabeli vállalkozások mindössze $17 \%$-a végez kutató-fejlesztő tevékenységet, ezen belül is a termékfejlesztés meghatározó. A vállalkozások $83 \%$-a egyáltalán nem végez $\mathrm{K}+\mathrm{F}$ tevékenységet. Ez is azt az országos statisztikát támasztja alá, hogy $\mathrm{K}+\mathrm{F}$ területen még mindig igen elmaradott az ország, de különösen északkeleti térsége (azaz Szabolcs-Szatmár-Bereg megye). Magyarországon jelenleg a kutatás-fejlesztésre fordított GDP hányad 1,2\% körül van, ami messze elmarad az Európai Unió átlagától, a lisszaboni stratégiában meghatározott 3\%-os célkitüzésről nem is beszélve (Török 2005). A mintabeli összefüggések tekintetében az alkalmazotti kompetenciák közül kizárólag a nyelvtudás áll szignifikáns kapcsolatban a kutatás-fejlesztéssel (Cramer's $\left.{ }^{3} \quad \mathrm{~V}=0,33\right)$. Ugyanakkor az előző kérdésben megállapítottam, hogy a nyelvtudás és a személyes kapcsolatrendszer között kimutatható kapcsolat van, így arra következtethetünk, hogy a kapcsolati tőke közgazdaságilag csupán közvetetten áll összefüggésben a kutatásfejlesztéssel, de ez az összefüggés logikailag igazolható (jóllehet statisztikailag nem szignifikáns).

A kompetenciák egymás közötti kapcsolatait megvizsgálva (10. kérdés) arra a következtetésre jutottam, hogy a személyes kapcsolatrendszer leginkább a nyelvtudással hozható összefüggésbe, ami azt bizonyítja, hogy a kapcsolati tökének fontos elemét jelentik a külgazdasági kapcsolatok, valamint a külföldi piacokon való megjelenés és terjeszkedés.

A 11. kérdés a vállalkozások jövőbeli foglalkoztatási terveire irányult, melynek eredményei: a mintabeli vállalkozások döntő többsége $(90 \%$-a) szinten kívánja tartani a foglalkoztatást, 6\%-uk a jövőben bővíteni kívánja a foglalkoztatottak számát. Szintén kedvező jelenség, hogy elbocsátást a vállalkozások mindössze 4\%-a tervez.

Végül az utolsó (12.) kérdés a vállalkozások és az oktatás kapcsolatrendszerét vizsgálta. A minta vállalkozásainak több mint kétharmada biztosít szakmai

${ }^{3}$ A Cramer-féle asszociációs együttható az asszociációs kapcsolat szorosságának méröszáma. $C^{2}=\frac{\chi^{2}}{N \min \{(r-1)(c-1)\}}$, illetve $C=\sqrt{C^{2}}$ (Hunyadi-Mundruczó-Vita, 2001). 
gyakorlóhelyet, vagy szakképzésben, vagy felsőoktatásban részt vevők számára, mintegy 34\%-uk azonban egyáltalán nem foglalkozik gyakorlati képzéssel. Mindemellett a vállalkozások 31\%-a szakképzésben részt vevőknek, 35\%-a felsőoktatásban részt vevőknek biztosít szakmai gyakorlóhelyet, viszont meglehetősen korlátozott számban (leginkább 2-3 fỏ részére).

A személyes kapcsolatok nem állnak összefüggésben sem a jövőre vonatkozó foglalkoztatással, sem pedig a szakmai gyakorlattal.

\section{Összegzés}

Az elméleti áttekintés alapján megállapítható, hogy a téma kereteit biztosító három kulcsfogalom - elit, vállalkozó, kapcsolati tőke - között számos ponton összefüggés tárható fel. Az elit fogalmán belül ugyanis megkülönböztethető a gazdasági elit, melynek szükebb értelmezése azonosítható a vállalati elittel, mint a vállalatot irányító személyekkel. Számos elmélet foglalkozik továbbá a vállalat és vállalati elit, valamint a kapcsolati tőke viszonyával.

Az általam megfogalmazott álláspont szerint a kapcsolati tőke elméleti síkon formalizált és nem formalizált, ún. szubjektív elemekre bontható. A formalizált elemek egy adott vállalkozás szerződéses kapcsolatai alapján vizsgálhatók, míg a szubjektív elemek csak indirekt úton, a vállalati vezetők révén elemezhetők.

A szubjektív elemek saját empirikus kutatásom alapján történő vizsgálata kapcsán megállapítható, hogy a kapcsolati tőke a legfontosabb vállalati jellemzőkkel szignifikáns kapcsolatba hozható, így nemcsak a vállalkozások belső folyamataira van lényeges hatással, hanem közvetetten egy nemzetgazdaság egészében fontos gazdasági tényező. Előfeltevésem tehát igazolást nyert, hiszen a kapcsolati tőkére vonatkozó összefüggések iránya és mértéke a megfelelő statisztikai próba segítségével igazolható.

\section{Felhasznált irodalom}

1. BECKER S. G. (1996): Accounting for Tastes. Cambridge, Harvard University Press

2. BENDIX R. - HOWTON F. W. (1967): Social Mobility and the American Business Elite. In: Social Mobility in Industrial Society. Berkeley: University of California Press 
3. BOSMA N. - PRAAG M. - THURIK R. - WIT G. (2002): The Value of Human and Social Capital Investment for the Business Performance of Start-ups. Tinberger Institute, Discussion Papers, March: 027/3.

4. BOURDIEU P. (1998): Practical Reason: On the Theory of Action. Stanford University Press

5. BURNHAM J. (1965): A ,managerek” forradalma, vagy mi történik most a világban. In: Balogh J. (szerk.): Modern polgári szociológia. 2. kötet, Budapest, 7-83.

6. BYGREVE W. ED (1997): The Portable MBA in entrepreneurship. John Wiley \& Sons, Inc New York

7. FAFCHAMPS M. - MINTEN B. (2002): Returns to Social Network Capital among Traders. Oxford, Economic Papers, 54, 173-206.

8. FALUS IVÁN - OLLÉ JÁNOS (2008): Az empirikus kutatások gyakorlata. Nemzeti Tankönyvkiadó, Budapest

9. FÜLÖP GYULA (2004): Kisvállalati gazdálkodás. Aula Kiadó, Budapest, 15-17.

10. GALASI PÉTER (1994): A munkaerőpiac gazdaságtana. Aula Kiadó, Budapest

11. HERBERT R. F. - LINK A. N. (1982): The Entrepreneur-Mainstream Views and Radical Critiques. Praeger Publisher, New York

12. HISRICH R. D. - PETERS M. P. (1991): Vállalkozás. Új vállalkozások indítása, fejlesztése és működtetése. Akadémiai Kiadó, Budapest. 6.; 12.

13. HOFFERTH S. J. - BOISJOLY J. - DUNCAN G. (1999): The Development of Social Capital. Rationality and Society, 11(1): 79-110.

14. HUNYADI LÁSZLÓ - MUNDRUCZÓ GYÖRGY - VITA LÁSZLÓ (2001): Statisztika. Aula Kiadó, Budapest, 111.; 115.; 124.; 169.

15. KÁLLAY LÁSZLÓ - IMREH SZABOLCS (2004): A kis- és középvállalkozás-fejlesztés gazdaságtana. Aula Kiadó, Budapest

16. KILBY P. (1971): A Macrosociological Interpretation of Entrepreneurship. The Free Press.

17. LASWELL H. D. (1934): World Politics and Personal Insecurity. Chicago

18. LIN N. (2001): Social Capital. Cambridge: Cambridge University Press

19. MAKSZIM GYÖRGYNÉ (2010): Statisztikai helyzetkép SzabolcsSzatmár-Bereg megye vállalkozási szerkezetéről Gazdasági és Társadalomtudományi Közlemények, Nyíregyházi Főiskola, Gazdasági és Társadalomtudományi Kar, Krúdy Könyvkiadó, Nyíregyháza, II. évfolyam 2. szám, 6577. (ISBN 978-963-9909-78-6)

20. MAKSZIM GYÖRGYNÉ (2011): A new Element - the Role of Networking Capital in Explaining the three main Questions of Corporate Theory Journal of Economic and Social Studies, Special edition in English, 
The College of Nyíregyháza, Faculty of Economics and Social Studies, Hungary, Nyíregyháza, 61-69. (ISBN 978-615-5097-25-6)

21. PARETO W. (1972): A kormányzó elit. In.: Huszár Tibor - Somlai Péter (szerk.) A polgári szociológia története 1917-ig/4. Budapest: Tankönyvkiadó, 278-283.

22. RÓNA-TAS ÁKOS - BÖRÖCZ JÓZSEF (1997): Folyamatosság és változás az államszocializmus utáni bolgár, lengyel, cseh és magyar üzleti elitben. Szociológiai Szemle, 2.

23. SCHUMPETER J. A. (1980): A gazdasági fejlődés elmélete. Közgazdasági és Jogi Könyvkiadó, Budapest

24. TÖRÖK ÁDÁM (2005): A Lisszaboni program értékelése és kibontakozásának esélyei. Társadalom és Gazdaság, 27. évf. 1-2. sz., 13-25.

25. VECSENYEI JÁNOS (2002): Vállalkozás. Az ötlettől az újrakezdésig. Aula Kiadó 14.;17.

Makszim Györgyné: okleveles közgazdász

Nyíregyházi Főiskola, Gazdálkodástudományi Intézet, 4400 Nyíregyháza, Sóstói út 31/b 